\title{
THE PRINCIPLE OF GENDER EQUALITY AND THE FUNDAMENTAL RIGHTS AND GUARANTEES OF PARTICIPATION OF WOMEN IN UNION ORGANIZATIONS IN BRAZIL
}

\author{
Candy Florencio Thomé \\ Rodrigo Garcia Schwarz ${ }^{2}$
}

\begin{abstract}
This article aims to study the importance of women workers' participation in the governing bodies of trade unions as a way to combat gender inequality in the labor market. There is a significant number of legal rules applicable in the Brazilian legal system in order to combat gender inequality, with a repressive approach. However, the negative consequences of the sexual division of labor persist, perpetuating stereotypical gender roles. It is imperative, therefore, not only the guarantee of equal wages and working conditions and protection against negative discrimination, but also to guarantee women's access to the labor market, through affirmative actions. In this sense, women workers' participation in trade unions activities is a major way to ensure this access, as it enables women's empowerment, providing greater possibility for women to exercise power and citizenship in the public sphere in which democracy is constructed, and greater legal legitimacy of conventional norms regarding gender equality, given the normative role of unions. For that, the implementation of affirmative actions is necessary in order to combat the difficulties in women's participation in these decision-making bodies.
\end{abstract}

Keywords: fundamental rights; gender; positive discrimination; trade union; women.

\section{INTRODUCTION}

This article aims to study the importance of the participation of women workers in trade union organizations as a way to combat gender-based inequality, by analyzing the configuration of international and national legal norms for the protection of the principle of equality and the study of the persistence of these genderbased inequalities, especially in the labor market.

In this paper, we analyze the principle of equality and its effects on gender relations, from the viewpoint of their insertion in the field of human and social rights, the relationships between social rights and human rights, the

\footnotetext{
${ }^{1}$ Pós-doutorado pela Pontifícia Universidade Católica de São Paulo, pela Universidad de Manizales e pela Universidad Nacional de Córdoba. E-mail: candyflor@gmail.com

${ }^{2}$ Professor Doutor do Programa de Pós-graduação em Direito da Universidade do Oeste de Santa Catarina (UNOESC) e Visiting Professor da ADAPT - Università degli Studi di Modena e Reggio Emilia. Pós-doutorado na Universidad Nacional de Córdoba (Argentina), na Pontifícia Universidade Católica de São Paulo (Brasil), na Universidad de Manizales (Colômbia), na Fundación
} 
characteristics of indivisibility, universality and the interdependence of these rights, the relationships between social rights and equality in gender relations and the consequent need for specification of the subjects of human rights as well as the relationships between the Welfare State, social spending cuts and gender-based inequality.

For a better understanding and location of the subject in time and space, the main theories of feminis $m$ are studied, as well as the various consequences of the sexual division of labor, such as the existing wage gap, vertical discrimination, horizontal discrimination, the relationship models among work and family, the precariousness and insecurity of women's work and the sexualization of unemployment, direct discrimination and indirect discrimination, as well as the intersectionality of discriminations.

Finally, the importance of work and collective struggle in the effective scope of the gender equality law is examined, as well as the foundations that underlie the need to promote women's participation in decision-making bodies of trade unions.

Given the need to promote women's participation in trade unions, especially in their governing bodies, the main actions that unions take and can take to promote women's participation in leadership and deliberating bodies of unions are analyzed from the point of view of its effects on the achievement of gender equality and of their compliance with the Brazilian legal system, with respect to the features of the Brazilian trade union organization.

\section{HUMAN RIGHTS, SOCIAL RIGHTS AND THE PRINCIPLE OF GENDER EQUALITY}

Human rights are rights enshrined in the international treaties and considered, in such international norms, as rights to which all people are subject by the simple fact of their humanity (COMPARATO, 2003, p. 12). Such rights are paradigms and ethical frameworks that guide the contemporary international order (PIOVESAN, 2007, p. 118).

Human rights stem from the basic principle of human dignity, introduced by the Universal Declaration of 1948 and subsequently consolidated by the Declaration of Human Rights in Vienna, in 1993². Such rights are a consequence of a symbolic space of struggle and social action in the struggle for human dignity, making up an emancipatory axiological construct (PIOVESAN, 2007, p. 110), for, as Comparato notes (2003, p. 21), human dignity consists of the fact that the human being is a being regarded and treated as an end in itself, and never as a means to achieve a result, and the fact that, by their own rational will, only human beings live in conditions of

Centro Internacional de Educación y Desarrollo Humano (Colômbia) e na Universidade de Coimbra (Portugal). E-mail: rgschwarz@gmail.com

${ }^{3}$ According to Piovesan (2007, p. 137), "Human dignity as the foundation of human rights and intrinsic value to the human condition is a conception that, later, came to be incorporated by all human rights treaties and declarations, which went on to integrate the so-called International Human Rights Law“. 
autonomy, that is, as being able to be guided by the laws that they modify.

Sarlet, after warning that the definition of human dignity is quite complex due to its ambiguity, porosity and its necessarily polysemic nature, states that some basic outlines can be given, while noting that said concept is constantly under construction and development ${ }^{4}$. Thus, the author asserts that human dignity is the intrinsic quality of the human person, unable to be renounced and inalienable - an element that qualifies the human being, that can not be removed. Said human dignity implies that it would be violated in the case that indispensible goods for life were taken away, if deep and lasting physical or mental pain were inflicted to any person, or if their status as a subject of rights were denied or diminished (SCHWARZ, 2011, p. 31), resulting in unsubmissiveness to oppressive or humiliating living conditions, while connected, meanwhile, to the satisfaction of needs that allow one to achieve their own objectives and participate in the construction of social life, constituting a central element in modern justifications of human rights (Pisarello, 2007, p. 39).

Human rights, among which is included the right to equality, have as core characteristics universality, indivisibility and interdependence, established by the Universal Declaration of Human Rights of 1948, when putting together the list of civil and political rights with economic, social and cultural rights, combining the value of freedom with the value of equality ${ }^{5}$.

All human rights are founded on the principle of human dignity and are universal, indivisible and interdependent. The satisfaction of social rights is essential for the existence of civil and political rights, which require having achieved a situation of basic human needs in order to be fully exercised. In turn, civil and political rights are essential as control mechanisms of the fulfilment of obligations arising from social rights. The development of a human right facilitates the development of other rights, and the lack of one right also affects the others. Thus, the violation of social rights generates a reflexive violation of civil and political rights, to the extent that economic and social vulnerability leads to the vulnerability of civil and political rights, with the same occurring in the violation of civil and political rights, implying the vulnerability of social rights.

In short, for the effective guarantee of human rights, it is necessary that both civil and political rights as well as social rights are accessible to all human beings, as human rights are an integral, single and indivisible complex (PIOVESAN , 2007, p. 142), reaching even the social groups that do not usually have access to such rights, paving the way for a non-exclusive, democratic citizenship, and with a project of social transformation (SCHWARZ, 2011, p.39).

\footnotetext{
${ }^{4}$ Sarlet (2007, p. 40-43) further states that the difficulty in conceptualizing human dignity must not be a hindrance nor a foundation for its lack of conceptualization, for "when trying to assess the existence of violations to dignity, there is no way to do without (...) a clarification as to what is meant by a person's dignity, precisely so that we can observe and (...) curb any potential violations".

${ }^{5}$ Piovesan (2007, p. 137-141). According to the author (2007, p. 134) in a session that created the Human Rights Council on April 3,2006 , the UN reiterates its acknowledgement that human rights are interrelated and interdependent.
} 
Social rights can be defined as those related "to the protection of economically weakened individuals with aim of obtaining social balance, the common good, the right to satisfy the vital needs of the individual as a member of the community, with a joint effort of legal institutes for the efficiency and effectiveness of the norms of social rights," with collective interest prevailing over private interest, for social rights (CARVALHO, COSTA, 2010, p. 11-13). They are, in large part, products of the criticism of the inadequacies and distortions of the liberal model (ABRAMOVICH, COURTIS, 2006, p. 12).

According to Pisarello (2007, p. 11), social rights are rights that are linked to expectations of satisfying the basic needs of people in various areas, such as in employment, housing, health, food and education. The recognition of these expectations entails positive and negative obligations, for both the public authorities as well as for individuals. To the extent that the goods protected by social rights are related to the survival and enjoyment of material conditions that enable the effective exercise of liberty or autonomy, the revindication of social rights are of interest, potentially, to all people. However, in a special way, it is of interest to the society members who are in vulnerable situations, whose access to resources for said survival and enjoyment is generally residual, or even nonexistent.

Despite the universality, indivisibility and interdependence of human rights, social rights are often treated as rights that are not part of human rights or, when treated as such, are labeled as a specific form of human rights that does not imply the same analysis, application and effectiveness of other rights. Much of the doctrine tends to regard them as mere letters of informative principles or as programmatic rights, without being exigible on the part of their owners.

The persistent violation of social rights is mainly related to the material inequality of power existing in contemporary societies, but the perception of social rights as rights that are not part of human rights or that have less importance than civil and political rights also plays a considerable role in this violation ${ }^{6}$. This is because the perception of social rights is founded on a number of theses that delineate the perception of social rights and ultimately undermine their effective application and protection, with the main ones being the theses of historical perception, of philosophical perception, theoretical perception, and dogmatic perception ${ }^{7}$. However, these human rights had different configurations throughout history, taking into account the society in which they arose and their subjects, with no linearity in the emergence of human rights. In addition, all human rights are related either with the right to freedom or with the right to equality, and all human rights, without exception, are of ambivalent

\footnotetext{
${ }^{6}$ According to Pisarello (2007, p. 16), "if in current media societies human decisions depend in large part on the perception that one has of reality, an essential requirement to remove obstacles preventing the exercise of social rights consists in counteracting the biased political and legal view that one has of said obstacles, and in offering an alternative view".

${ }^{7}$ For an in-depth critique of this split between social rights and civil and political rights, see Pisarello (2007). The author warns, however, that although these theses belong to different planes of the dominant legal and political discourse, they are not expressed in rigid limits, nor in a totally differentiated way (Pisarello, 2007, p. 16).
} 
nature.

They are, therefore, all the human rights of complex configuration, partially positive, in part negative, partially costly, in part inexpensive, partially individual, in part collective, partially universal, in part specific (Pisarello, 2007 p. 75).

Human rights, and more specifically, social rights, in the past three decades have become permeable to a new type of revindication, not only linked to income distribution access, but linked mainly to demands of recognition. They are collective claims in sectors that are generally discriminated against; they demand the removal of legal, economic and social barriers that prevent or limit their participation or access to social spheres such as political representation, education or employment. Such "demands of recognition" have, among their main objectives, the visibility of this particular social group, with the recognition of their specific differences and the removal of those supposedly neutral guidelines that, in fact, turn out to represent the vision of the dominant groups and hinder access of discriminated groups to these guidelines. These demands have emerged, primarily, by the movements of women, blacks, indigenous people, homosexuals and ethnic minorities and/or religious minorities (ABRAMOVICH, COURTIS, 2006, p. 18).

Regarding the differences between the demands of redistribution - classic social rights demands - and demands of recognition, Fraser warns that all redistribution demands assume an implicit conception of recognition and that many demands of recognition assume an implicit conception of redistribution and that, in reality, any struggle against injustice, when properly understood, implies demands for both redistribution and for recognition, affirming, finally, that the groups formed by communities of sex and race are paradigmatic examples of groups that tend to claim both types of demands (FRASER, 1997, p. 12-19).

For the scope of the principle of gender equality, demands of both recognition and of redistribution are needed ${ }^{8}$. With the recognition of claims and the process of specification of the subjects of human rights, international organizations and their norms have gone on to address gender discrimination issues, establishing the principle of gender equality in various international treaties and conventions.

In the specific gender context, the Welfare State is intrinsically linked to issues of the sexual division of labor and combating discrimination against women at work, as the existence of this State facilitates the implementation of gender equality.

Therefore, how each State deals with the issue of $\operatorname{care}^{9}$ has direct consequences on gender equality.

\footnotetext{
${ }^{8}$ Fraser (1997, p. 18). In later work, Fraser (2010) adds a third dimension of justice, the political dimension; as such, with regards to the demands for justice, there are: demands of redistribution, of recognition and of representation, setting a three-dimensional conception of justice - that is, the economic, cultural and political dimension.

${ }^{9}$ Studies on care in Brazilian literature, as per Hirata (2010, p. 44-47), are still limited, with most studies done by the knowledge areas of nursing and gerontology. In this work, care is understood as the work, professional or not, paid or unpaid, for the care of children, elderly and people who need help to maintain their basic activities.
} 
Bjornsdottir examines the growing trend in many countries of the transformation of care into a problem of family responsibility, reducing its focus as a public policy, and how this shift to a conservative position affects gender equality given that, when the State begins to make the family responsible for the care of children and people in situations of dependence, this responsibility is aimed toward women, given the existing prejudice of a woman's vocation to care for others (BJORNSDOTTIR, 2009, p. 735).

Global inequalities have increased due to the limiting of free access to public services, with women being the ones who most suffer the consequences of the shrinkage of services covered by the State, since when the State cuts funds for the care of the young, sick and elderly, those who will shoulder such care in most cases are women, who are traditionally assigned these responsibilities, thus generating subsequent problems of inequality, since women who have the financial possibility will pay others to perform such services ${ }^{10}$, maintaining their careers and job opportunities, while those who do not have such financial possibility will work a double shift, excessively costly to their health and job opportunities ${ }^{11}$. Bertolin and Carvalho (2010, p. 192) also note that when there are public spending cuts imposed in areas such as education and health, women doubly suffer the effects of this instability, not only as users of such services, but also as professionals, since the totality of women working in the education and health sectors is very large.

Public policies whose objectives or outcomes are spending cuts in social rights put women as the hidden axis of balance or social compensation, since the decrease in public spending and reductions in social programs and privatization of services intensify the domestic work of women. By failing to take into account reproductive work, public policies increase women's workload within society to compensate for this decrease in provision of public services (CELIBERTI, MESA, 2010, p. 16).

This is due to the fact that a large part of the services provided by the State, in a Welfare State, is assistance, which in Brazil is part of the social security system provided for in art. 196 of the Constitution, together with Health and Social Security. This assistance, when it is not provided by the State, is often attributed to women, given the existing gender division of work in our society, which, in the form of domination, assigns women the care of family, children and dependents, with the argument that they have a "born vocation" for such services. Thus, when the State provides assistance and health care to citizens free of charge and effectively, the possibility for women to participate in public life increases. The reduction of these services thus ends up increasing gender inequalities, as it hampers women's access to work and public life.

Although the existence of social rights is necessary for the achievement of gender equality, their mere existence is not enough, because, among other reasons, of the fact that the main theories of the Welfare State have

\footnotetext{
${ }^{10}$ In this sense, see Crenshaw (2002).

${ }^{11}$ In this regard, see also Heinen (2000, p. 150).
} 
not taken into account the unequal position between men and women and its consequences in the provision of social services, and if the State has in some way improved the socioeconomic conditions of women, it has in another way ended up helping to perpetuate a series of gender-based prejudices. Women are the most affected by social spending cuts, even in a social State, given the dualization of the system, with a social security system that reaches men more than women and a system of social assistance whose target is a larger number of women, given capitalism's current male breadwinner paradigm.

Most social security systems ${ }^{12}$ were originally designed based on the male breadwinner model. This model is based on the perception of the male as head of the family and its provider, and the perception of women as mainly responsible for unpaid care work. In these systems, women were granted a form of protection derived from the protection that her husband had. Their gains from professional activities were considered additional to her husband's earnings. This attitude began to change only in the eighties, with the influence of the Welfare State of the Scandinavian countries (HEINEN, 2000, p. 148-149). Current legislation still tends to reflect this model, even if there are many improvements in present times.

The principle of equality, which is founded on the dignity of the human person, is a fundamental underpinning of the democratic State and a crucial principle in the structuring of a political and legal system, with one of its consequences being the principle of gender equality (LIMA, 2011, p. 45-49).

The UN has produced several standards on the right to gender equality; the following can be cited as such: the Convention for the Suppression of the Traffic in Persons and of the Exploitation of the Prostitution of Others, of 1949, the Convention on the Political Rights of Women, which obliges Member States to allow women to vote, be voted and to hold public office on the same terms as men, of 1952, the Convention on the Nationality of Married Women, which is aimed at the protection of married women's right to keep her nationality, of 1957, the UNESCO Convention Against Discrimination in Education, which enshrines equality in educational opportunity for men and women, including girls, the UN Convention on the Elimination of All Forms of Discrimination Against Women (CEDAW ) of 1979, and the UN Declaration of 1993 for the Elimination of Violence Against Women, which considers that violence against women is a crucial mechanism by which women are forced into a subordinate position compared with men.

The UN treaties on gender equality consecrate this principle in a general manner, as well as the need for women to be part of all decision-making processes, and consequently, the need to adopt positive measures with regard to the participation of women at all levels of government and in all public spaces, including the labor

\footnotetext{
${ }^{12}$ Social Security has several meanings, but in general, it can be defined as the protection which society provides for its members against the economic and social setbacks that would otherwise cause the decline or even the extinction of forms of income such as illness, maternity, work accidents, unemployment, age, death, etc., as well as protection for medical care and subsidies for families with children.
} 
market.

The ILO also has a number of specific norms for women's work. The first ILO Conventions on maternity protection and on nocturnal work were intended to protect women from exploitation in the workplace and protect their health, especially with regard to their reproductive role. These parameters were intended to protect women workers, seen as the weakest and most vulnerable, who needed special attention and consideration. Currently, the ILO norms have two basic concerns: equal opportunities, in order to ensure equal opportunities and access to training, employment promotion, organization and decision making, as well as ensuring equal conditions of remuneration and benefits of social security, provided due to the use and protection of women workers, especially with regard to working conditions that can pose risks to their reproductive health.

The main ILO norms on gender equality are: Convention no. 100 on equality of remuneration, Convention no. 111 on discrimination in employment and occupation, Convention no. 156 on women workers with family responsibilities, and Convention no. 183 on maternity protection. Other conventions, not yet specifically directed towards women, are important for gender equality, such as Convention no. 175 on part-time work, Convention no. 177 on household work, and Convention No. 189 for domestic work, since the majority of people working in such conditions are women.

International ILO conventions are very important tools in the fight against gender inequality. However, although there is a profusion of ILO norms on these matters or related to gender issues - demonstrating a concern from this international organization with regards to this issue - it is difficult to implement these norms in countries due to a lack of knowledge of these norms, as well as resistance to them.

Regarding MERCOSUR, there are not many norms establishing gender equality, just a few resolutions that point to the need for better research and analysis on the issue. Thus, the MERCOSUR Social and Labor Declaration provides, in the chapter on Individual Rights, art. 3, equal treatment and opportunities between women and men and the commitment to ensuring such equality of treatment through labor norms and practices, with some resolutions also setting forth provisions on gender equality, such as Resolution no. 84 of December 7, 2000, MERCOSUR/GMC/RES. no. 84/00, which states that the incorporation of a gender perspective involves establishing a clear and effective framework for supervision, monitoring and evaluation in order to achieve the objective of equality of opportunities, considering that such initiatives are essential to eliminate disparities and discrimination against women in the region (art. 1) and Resolution no. 20 Common Market Group (CMG) that created the MERCOSUR Specialized Women's Conference (SWC; [REM, Portuguese acronym]) in 1998 with the objective of "establishing a framework for the analysis of the situation of women in relation to the current legislation in the MERCOSUR Member States, as regards the concept of equal opportunities". Despite the existence of laws that recognize the importance of the transversality of gender in the preparation, implementation 
and assessment of the public policies of MERCOSUR member countries and that provide for transversal studies of gender with data disaggregated by sex in relation to the labor market, there are no other measures that protect or promote the labor market for women.

As for Brazilian national legal framework, the rules on women's work began to emerge more significantly with the Federal Constitution of 1934, which was the framework of the internalization of international social precepts, the beginnings of social constitutionalism in Brazil, and the constitution upon which the authority to legislate on labor rights passed onto the Union.

The principle of equality is provided in the Brazilian Federal Constitution of 1988, in a broad sense, in the preamble and art. 3, (sections I, III and IV). Its art. 5 states that all are equal before the law, without distinction of any kind, guaranteeing to Brazilians and foreigners residing in the country the inviolability of the right to life, liberty, equality, security and property, affirming that men and women have equal rights and obligations under this Constitution (section I), that the law shall punish any discrimination violating fundamental rights and freedoms (section XLI) and that the practice of racism is a criminal offense non-bailable and imprescriptible, subject to imprisonment pursuant to the law (section XLII).

In the specific context of gender equality and in the context of labor rights, the Brazilian Constitution in art. 7 establishes for workers: the right to the protection of the labor market for women (section XX) by means of specific incentives in accordance with the law and the right to prohibit any discrimination in terms of wages, exercise of functions and admission criteria on the grounds of sex, age, color or marital status (section XXX).

The Consolidation of Labor Laws contains a specific chapter for the protection of women's work, but it is a norm that was established in the 1940s, steeped in multiple protection [heterotutelares] characteristics, and therefore should be considered in conjunction with the principles of gender equality enshrined in the Federal Constitution of 1988, and with some related norms following the Constitution.

\section{THE SEXUAL DIVISION OF LABOR AND INEQUALITY ON THE GROUNDS OF GENDER IN THE LABOR MARKET}

The number of applicable norms which provide for gender equality in Brazil is significant, but such equality is still far from being achieved. Despite the existence of numerous norms at the international, community and national levels expressly prohibiting negative discrimination, inequalities still remain.

As per the 2005 Report of the United Nations on the Millennium Development Goals, women's access to employment is lower than men's in most developing countries: women have less chances of obtaining paid and stable employment, and work more often in the informal economy. These disadvantages have a negative impact on the development process and on the possibility of equalizing gender inequalities in every sector of life. 
Work is allocated differently among occupations in all societies. As in other areas, the labor market has very strong gender segregation, even taking into account the differences between regions and cultures.

Inequalities between men and women are essentially based on the sexual division of labor between productive work and reproductive work. This form of sexual division has two organizing principles: the principle of separation and the principle of hierarchy. The principle of separation concerns the existence of work considered feminine, in the reproductive sphere, and work considered masculine, in the productive sphere. The principle of hierarchy defines work typically considered as male as of higher value than work typically considered female ${ }^{13}$. There is no free choice of roles, as the determination of the functions of each gender is performed antagonistically, through the domination of men over women.

The sexual division of labor structures gender relations in society and establishes a naturalized division of the reproductive areas assigned to women and of the productive areas assigned to men. Thus, in addition to attributing to women the responsibility for reproduction, establishing their inclusion in production only secondarily, the sexual division of labor labels reproductive work as non-work, not giving it value and marginalizing it as an object of study of the economy.

The problem of reconciling between family life and professional life has always been crucial in establishing effective equality between men and women, since gender differences are a reflection of the differentiation of roles within the family. According to data from the Perseu Abramo Foundation/SESC [Social Service of Commerce] from 2010, out of the total number of women interviewed, $69 \%$ reported being responsible for housework, whereas out of the total number of men surveyed, only $3 \%$ answered that they were responsible for such work ${ }^{14}$. In terms of the average weekly time spent on housework in 2009, according to data from IBGE/PNAD [Brazilian Institute of Geography and Statistics/National Household Sample Survey], economically active women spent on average 22.4 hours a week on housework, while men spent only 9.8 hours. There are differences between men and women not only as regards the number of hours, but also in the type of work done in the home. When performing household work, men perform very specific tasks, such as maintenance and repair of appliances, care for children, shopping, taking children to the doctor or cooking a more sophisticated dish, which are tasks that lie exactly on the border between the public and private space (BRUSCHINI AND LOMBARDI, 2007, p. 52).

Wage inequality is one of the most persistent forms of gender discrimination in the labor market. According to Santos, women are systematically victims of pay discrimination. In practice, they are denied the fruition of the principle of equal pay for equal work laid down in the legal systems of most countries (SANTOS,

\footnotetext{
${ }^{13}$ Kergoat (2000, p.35-36). Reproductive work is understood as all the activities necessary for maintenance and human survival, such as care and education of children, food preparation, cleaning clothes, etc.

${ }^{14}$ Data from the Perseu Abramo Foundation/SESC [Social Service of Commerce] (2010).
} 
2005, p. 304$)$.

Women have the highest percentage of people who have more than twelve years of studies in relation to the total population, with a total average of $6.3 \%$ of women and $5.9 \%$ of men, as of 2009 , as well as in terms of the employed population, with a total of $8.7 \%$ of women and $7.7 \%$ of men $^{15}$. Similarly, among women are the most people who have completed higher education, with $10.9 \%$ of women versus $10 \%$ of men in the metropolitan region, $6.8 \%$ of women versus $5.1 \%$ of men in the non-metropolitan area, $9.2 \%$ of women versus $7.8 \%$ of men in urban areas, and $1.8 \%$ of women versus $1.1 \%$ of men in rural areas ${ }^{16}$.

Despite the greater amount of education, the wage gap between men and women remains high in Brazil. According to data from DIEESE/SEADE, MTE/FAT and PED of 2010, in Belo Horizonte, black male employees earned on average $R \$ 1,243.00$, non-black male employees $R \$ 1,812.00$, black female employees R \$966.00 and non-black female employees R \$1,428.00; in the Federal District, black male employees earned on average $R \$ 1,961.00$, non-black male employees $R \$ 3,151.00$, black female employees $R \$ 1,731.00$ and non-black female employees R \$2,626.00; in Porto Alegre, black male employees earned on average R $\$ 847.00$, non-black male employees $R \$ 1,218.00$, black female employees $R \$ 847.00$ and non-black female employees $R \$ 1,218.00$; in Fortaleza, black male employees earned on average $\mathrm{R} \$ 899.00$, non-black male employees $\mathrm{R} \$ 1,209.00$, black female employees $\mathrm{R} \$ 794.00$ and non-black female employees $\mathrm{R} \$ 1,041.00$; in Recife, black male employees earned on average $\mathrm{R} \$ 908.00$, non-black male employees $\mathrm{R} \$ 1,269.00$, black female employees $\mathrm{R} \$ 818.00$ and nonblack female employees R \$1,088.00; in Salvador, black male employees earned on average R $\$ 1,129.00$, non-black male employees $R \$ 1,980.00$, black female employees $R \$ 994.00$ and non-black female employees $R \$ 1,417.00$; and in São Paulo, black male employees earned on average $R \$ 1,164.00$, non-black male employees $R \$ 1,824.00$, black female employees R $\$ 42.00$ and non-black female employees R $\$ 1,417.00^{17}$.

These data demonstrate the persistence of the wage gap between men and women, regardless of the number of years of education that women have, emphasizing the differentiated value that is given to men's work and women's work.

Another one of the best-known pernicious effects of the sexual division of the work is vertical discrimination, also known as the "glass ceiling."The glass ceiling refers to the existence of a smaller number of women in positions of higher pay and decision-making as compared to the number of men in such positions.

Although women in Brazil have a greater number of years of schooling than men, this higher amount of education has not translated into a greater ability to obtain gainful employment, as it is not enough to break the

\footnotetext{
${ }^{15}$ Brazil (2010). Data from IBGE/PNAD [Brazilian Institute of Geography and Statistics/National Household Sample Survey]

${ }^{16}$ Brazil (2010). Data from IBGE/PNAD [Brazilian Institute of Geography and Statistics/National Household Sample Survey]
} 
difficulty in access to jobs and promotions for women. Rather, what is observed is that wage inequality between men and women increases with the amount of education ${ }^{18}$.

Another adverse effect of the sexual division of labor is the unequal distribution between men and women in different branches of economic activities, causing the concentration of a particular sex in a given branch. This form of distribution is, in fact, a consequence of the idea of the "maternal instinct," establishing the definition of so-called feminine tasks under the false naturalization of tasks that require "thin fingers," agility, concentration and discipline. With these occupational ghettos, differences in career progress are also explained by biologized arguments or arguments stating that women relate to work differently and are less competitive.

In Brazil, occupational ghettos are unchallenged and there are no mechanisms to incentivize women to take technical courses, generating an underutilization of female enrollment (SOUZA-LOBO, 2011, p. 282-283). Thus, according to 2009 data from IBGE, employed women are more concentrated in domestic services (17\%), in commercial and repair activities (16.8\%), and in education, health and social service activities (16.7\%). In these sectors, male employment rates are $0.9 \%$ for domestic services, $18.5 \%$ in commercial and repair activities, and $3.9 \%$ in education, health and social service activities. The sectors of economic activity in which there is less concentration of women are construction (0.5\%), transport, storage and communication sectors (1.5\%) and accommodation and food $(4.8 \%)^{19}$.

The insertion of women in the labor market has always been strongly marked by precariousness, but the feminization of unemployment and the instability of women's employment relations has been increasing over the years, with less regulation of their guarantees of working conditions, lower wages and an increase in forms of homeworking, even if in general they have a higher educational level than men. This increase in women's participation in the formal and informal labor market occurs mostly in unstable jobs that are socially devalued and with almost no possibility of promotion and career, and with limited or no social rights, both in Asia and in Europe and Latin America (HIRATA, 2009, p. 88-89).

This flexibility perpetuates the sexual division of labor to the extent that, in most cases, stable work with an employment connection (formal work) is reserved for men, with management positions; meanwhile, women are assigned flexible (precarious) work, often without employment connection (informal), and without a management attribution.

One of the similar and problematic points of the two forms of precariousness of women's work -

\footnotetext{
${ }^{17}$ Brazil (2010). Data from DIEESE [Inter-Union Department of Statistics and Socio-Economic Studies]/SEADE [State System of Data Analysis Foundation], MTE [Ministry of Labor]/FAT [Worker Protection Fund] and PED [Survey of Employment and Unemployment].

${ }^{18}$ Brazil (2010). Data from DIEESE [Inter-Union Department of Statistics and Socio-Economic Studies]/SEADE [State System of Data Analysis Foundation], MTE [Ministry of Labor]/FAT [Worker Protection Fund] and PED [Survey of Employment and Unemployment].
} 
whether it is part-time hiring, typical in northern countries, or whether it is informal work, typical of southern countries - is the difficulty that women who exercise such activities have in associating, forming groups and joining trade unions, due to their isolation or the conditions of work time flexibility imposed by companies.

Women also constitute a majority in one of the most precarious jobs that exist: domestic employment. In $2009,17 \%$ of working women were in the domestic service sector, while $0.9 \%$ of working men were in the domestic service sector ${ }^{20}$. In absolute numbers, out of the 7,223,000 domestic workers in Brazil in 2009, 6,719,000 were women and only 504,000 were men. In addition, out of these men, nearly half had a formal contract (226,000), whereas for women, only 1,769,000 had an employment record book issued; that is, in addition to already being a majority in precarious work such as domestic work, most female domestic workers do not even have an employment record book issued ${ }^{21}$. Since domestic work is identified and naturalized as a female role and not as work, domestic employment is regarded as a particular form of employment in which relations are not regulated in the same way as in other employment relationships, thus the Brazilian legal system itself denies various rights to female domestic workers.

A woman already suffers a series of discriminations at the time of looking for a job. Recruitment policies often demand requirements that are not indispensable to work in certain jobs, and certain actions or requirements in selections for job openings end up harming more women than men, creating a sort of discrimination called indirect discrimination.

Direct discrimination tends to occur due to legal issues or religious norms that prohibit women from participating in work activities in the same way that men participate, with laws that prohibit or restrict the participation of women in employment contracts or that determine that a woman should be paid less than a man.

Indirect discrimination based on gender, in turn, is the situation whereby an apparently neutral provision, criterion or practice puts people of one sex at a particular disadvantage with respect to people of the other sex, unless that provision, criterion or practice can be objectively justified in consideration of a legitimate objective and that the means to achieve said objective are necessary and appropriate. This discrimination may be unclear in a preliminary analysis, but may be perceived after analyzing the actual effects of such situations ${ }^{22}$.

When analyzing the issue of gender in labor relations, one should take into account that certain groups of women are more affected by discrimination than others. This normally occurs with socially vulnerable groups, such as women's groups working in rural areas, black women, migrant women, girls, elderly women or those with a disability. In such cases, the discriminations are potentiated by the presence of other types of discrimination. This

\footnotetext{
${ }^{19}$ The sectors of "other industrial activities" (0.3\%) and "ill-defined activities" (0.0\%) were left out.

${ }^{20}$ Brazil (2010). Data from IBGE/PNAD [Brazilian Institute of Geography and Statistics/National Household Sample Survey]

${ }^{21}$ Brazil (2010). Data from IBGE/PNAD [Brazilian Institute of Geography and Statistics/National Household Sample Survey]

${ }^{22} \operatorname{ILO}(2007$, p. 50).
} 
phenomenon is called, among other names, multiple discrimination or discrimination of intersectionality (CRENSHAW, 2002, p. 171). In Brazil, the most common cases of intersectionality of discrimination are of gender and race.

Although there are many legal norms aimed at combating gender-based inequality, with a repressive approach, the harmful consequences of the sexual division of labor persist, perpetuating stereotypical gender roles. The precariousness and insecurity of women's work ultimately reinforce the attribute of naturalness applied to the characteristics required of the female labor force, which are for that very reason not considered as a professional qualification.

Faced with the persistence of gender-based inequalities in Brazil, it is necessary for all social actors, including the State and labor unions, to act in the fight against inequality through other instruments in addition to the traditional mechanisms of negative sanction against discrimination. It is essential, therefore, not only to guarantee equal pay, working conditions and protection against negative discrimination, but also to guarantee women's access to the labor market through affirmative action measures.

Affirmative action is provided for in the Brazilian legal system, as the Constitution of 1988 lists, as a fundamental principle among the objectives of Brazil, the construction of a free society, with justice and solidarity, through the reduction of social inequalities and the promotion of the good of all, without any form of discrimination (article 3, sections I, III and IV). Likewise, the fundamental norm establishes the right to the protection of the labor market for women (art. 7, section XX), through specific incentives according to the law and determination by means of law that will define its criteria of acceptance, of percentage of reservation of public office and public sector employment for people with disabilities (art. 37, sec. VIII).

The principle of equality is a complex principle that has two sides, that is, the positive side and the negative side. Thus, we must make a distinction between negative discrimination, which is prohibited in international and national norms in most countries, and positive discrimination. The latter is related to preferential treatment for underrepresented groups, in order to achieve the principle of equality. Piovesan considers that equality presupposes forms of social inclusion, and negative discrimination involves violent exclusion and intolerance to difference and diversity, thus a prohibition of exclusion does not result, automatically, in inclusion. Therefore, it is necessary to have a promotional approach towards equality in order to guarantee de facto equality, with the effective social inclusion of groups that have suffered and suffer a consistent pattern of violence and discrimination (PIOVESAN, 2007, p. 189-191).

Although more commonly advocated and implemented by the executive and legislative branches and configured as public policy, in these cases, positive discrimination measures may also be implemented by other social actors, such as labor unions, associations and companies, as already occurs, for example, with the labor 
unions, since many of them stipulate quotas on their boards.

Positive discrimination measures go far beyond the determination of public policies that guarantee the entry of women into the labor market, as they also concern access to vocational training and positions of responsibility and more refined qualification; however, for this, it is necessary to have the participation of all social actors involved in a committed way, since the effectiveness of a norm, especially a promotional norm, depends on the maturity of cultural sensitivity and on the ability of labor unions to effectively address the issue of women's work as one of their problems.

\section{THE ROLE OF TRADE UNIONS IN THE FIGHT AGAINST GENDER-BASED INEQUALITY}

The study and appreciation of a democratic citizenship that recognizes the diversity and plurality of women's citizenship is important, since the realization of social rights is only possible through the consolidation of democracy. This democracy, in turn, can not do without citizenship, since legal institutions can end up becoming instruments of social oppression when there is no participatory democracy and strengthening of citizenship (SCHWARZ, 2011, p. 8-9). Thus, not only the construction of social rights is necessary, but also that of instruments of citizenship protection in an inclusive context and in permanent construction.

With regards to defining the content of the norms on gender equality, Habermas (1997, p. 159-160) states that the feminist movement, having experienced the specific limitations of both paradigms mentioned above, would now be in a position to deny blindness with respect to the factual inequalities of the paternalistic social model.

Habermas (1997, p.169) goes on to state that "no regulation, no matter how sensitive it is to the context, can adequately realize the equal right to an autonomous configuration of private life, if it does not at the same time strengthen the position of women in the public political sphere, promoting their participation in political communication, in which it is possible to clarify relevant aspects for a position of equality. Having become aware of this link between private and public autonomy, present-day feminism has reservations against the model of a policy oriented towards instrumental, short-term successes; this explains the importance that feminism attaches to identity politics, that is, the forming effects of awareness, derived from the political process itself'.

For the German philosopher such a legal paradigm is inconsistent, however, with the projects of an "identity of the sexes in a just society," mandatory for all. The fact that the legal regulations regarding women are designed in an androgynous way or within an essentialist dualism of the sexes, under the sign of femininity or motherhood, does not change things. On the other hand, a proceduralist understanding of law opens a perspective for the determinate negation of identifiable injustice here and now, "even though we can not know a priori how the 
good society will be, we know more than enough about what it will not be, in order to establish a plan of action. It will not be a society with large disparities between the sexes in terms of status, power and economic security. Nor will it be a society that limits the freedom of choice of women with respect to reproduction, that tolerates poverty, violence, racial injustice, nor structures jobs without regard to the needs of families. Finally, and fundamentally, it shall not be a society that refuses to many of its members the substantial power of defining their daily existence. To cover all of its potential, feminism must hold a vision that is concerned not only with the relations between men and women, but also with relations between men and between women. Engagement in favor of gender equality, which gave birth to the women's movement, is necessary but not sufficient to express the basic values of this movement" (HABERMAS, 1997, p. 168-169).

The author concludes that to resolve the tension between equality and differences in gender relations, it is necessary that all those involved are heard, in order not to run the risk of prejudging or speaking on behalf of anyone ${ }^{23}$. So, the way in which the identity of the sexes and their relations will be interpreted will depend on constant public discussion, in which those concerned can themselves reformulate the issue or subject in question to be recognized, and they themselves may decide what needs they require to be corrected through law. In his work The Inclusion of the Other, the author reiterates the broad outlines of his thought concerning women's movements and women's rights (HABERMAS, 2004, p. 303-306).

It shares Habermas' idea that the subjects involved must themselves organize the protection of their rights, also emphasizing the importance of the role of women in unions for the legitimacy of gender rights equality. His analysis, however, is not sufficient to account for the whole transversal issue of gender and of perpetuated domination that permeates various fields. The author also does not reflect on the sexual division of labor and women's much larger load with reproductive work, restricting their ability to participate in political decisions and resulting in a greater need on the part of women for social benefits provided by the State such as maternity leave, child care, aid and nursing homes, etc., since this universality is defined by the identification of experiences of a specific group of people as a paradigmatic argument of humans in general (white people, adult, male, Western, owners or liberal professionals).

Two scholars of feminist movements that analyze Habermasian discourse theory, pointing out problems of androcentrism and ethnocentrism and starting from a specifically masculine neutral-universal model, are Fraser and Benhabib. It is stated, in accordance with the opinion of Fraser and Benhabib, that Habermas' theory is a necessary starting point, since communicative rationality, despite its demanding requirements, speaks the

\footnotetext{
${ }^{23}$ Habermas (1997, p. 178-169). In the same sense, see Pisarello (2007, p. 52): "the only way of distancing the ghost of arbitrariness is by using the resource of intersubjectivity and democratic deliberation. Thus, the inclusive and plural guarantee, both of basic as well as instrumental needs, both of those that ensure social homogeneity as well as those that facilitate cultural diversity, appear as
} 
language of inclusion but lacks the recognition of alternative publics and the recognition of several public spheres, that is, the recognition of not only a social pluralism, but of a legal pluralism as well ${ }^{24}$.

Habermas builds his theory based on the existence of a public sphere and a private sphere, which together constitute what the author calls the two institutional orders in the world of modern life, based on division, on the part of modern societies, between system and life-world, placing on the one hand the official capitalist economy and the modern administrative State, and on the other hand placing the family unit and the public sphere. The life-world is thus separated into two spheres which, in turn, provide complementary environments suitable for both systems: the private sphere, the family unit, which is linked to the official economic system, and the public sphere, that is, the space for political participation, debate and opinion, which is linked to the State administrative system. Fraser (1997, p.85-89) considers that there can be no a priori definition of this concept and that even the determination of what is and what is not public should be placed under discussion, since determining the family unit in advance as something private perpetuates male dominance, and it should be considered as a problem of common interest exactly what is decided.

Fraser (1997, p.85-89) also considers that the characterization of the family as a field of symbolic reproduction that is socially integrated compared to the place of paid work as a field of material reproduction that is systemically integrated, tends to exaggerate the differences and obfuscate the similarities between them, blurring, for example, the fact that both within the family and in the context of paid work there is labor and the fact that both within the family and in the context of paid work, women tend to be targeted for occupations that are sexualized, ghettoized and focused on the service sector.

Nor does Habermas consider the subordination of women to men both within the family and in the context of paid work, and does not take into account the gendered roles in society when criticizing the Welfare State, not looking at the fact that those most affected by social spending cuts and the reduction of social rights in the liberal model are women, nor perceiving the dualization of the social State, with a social security system that serves men more, and a welfare system that serves a larger number of women, given the existing male breadwinner paradigm in capitalism (FRASER, 1985, p. 107 and 122).

Fraser also points out another issue on which Habermas does not see the issue of gender in his theory: for the German scholar, the exercise of citizenship lies basically in political participation in debates and formation of public opinion. Thus, citizenship depends crucially on the ability to speak, the ability to participate, on an equal footing with others in dialogues and discussions. In classical capitalism, however, these capabilities are connected

inseparable from an ambitious conception of democracy, concerned about making audible, at all times, the voice of those involved in its construction, beginning by those who, for whatever reason, are in a position of specific vulnerability".

${ }^{24}$ In this sense, see Fraser (1985; 1995; 1997) and Benhabib (1992; 2007). 
with masculinity. They are abilities that are denied to women in many ways ${ }^{25}$; there is, thus, a clear dissonance between femininity and dialogical skills that are central to Habermas' concept of citizenship, making the citizen's role primarily a male one (FRASER, 1985, p. 115-116).

In addition, Fraser (1997, p. 83) considers that Habermas's theory excludes women because networks of cafés, casinos and discussion clubs that acted as highways of communication and dialogical rationality, which gave rise to the appearance of the concept of public opinion and institutionalizing the public sphere as res publica, had the practices and ethos of a male elite.

The author believes that the reconstruction of the gender issue, with an emancipatory transformation of capitalist societies with male dominance, requires a transformation of gender roles and institutions that mediate them. To the extent that the male/female worker role and the male/female caregiver role are so fundamentally incompatible with each other, the universalization of one or the other is not possible for the inclusion of both genders (FRASER, 1985, p. 119).

Benhabib, in turn, acknowledges that there is a fundamental moral right which is the "right to have rights" of every human being, in the sense that every human being has the right to be recognized and protected as a legal person by the global community, understanding human rights as moral principles articulated in such a way as to protect the communicative freedom of individuals, with these distinct moral principles being different from the legal specification of rights, although there is a necessary connection between human rights as moral principles and their legal forms ${ }^{26}$. The "right to have rights" involves recognizing one's identity with both a "Generalized Other" as well as with "Concrete Other". The view of the "Generalized Other" requires that each one holds the same rights and obligations, since the point of view of the "Concrete Other" requires that each person is seen as an individual with an affective-emotional constitution, both in their individual and their collective identity.

Benhabib, however, criticizes Habermas' position that these norms can be properly articulated in terms of a dialogue between the "Generalized Others" (CANADAY, 2003, p. 52) and proclaims the need for a universalism that is interactive, non-legislative, aware of gender differences and not gender-blind, contextually sensitive and not indifferent to the situation. Thus, the "Generalized Other" is associated with an ethic of justice and a moral category of rights. The "Concrete Other," in contrast, is a unique individual with a history and particular needs (CANADAY, 2003, p. 58-59). Thus, one should not yield to the tension between universalism and specificities, choosing one and denying the other, but rather should negotiate their interdependence by placing the universal in concrete contexts.

\footnotetext{
${ }^{25}$ These abilities are very important for union activity.

${ }^{26}$ Benhabib (2007, p. 9-11). The author acknowledges that she took the phrase "right to have rights," which was first coined by Hannah Arendt, but with a different meaning from the one used, initially, in political rights, identified as the right to be a member of a political community.
} 
Both Fraser as Benhabib consider that the strict limits established by Habermas between the public and private spheres perpetuate stereotyped gender roles and male dominance, considering that the public sphere should also cover issues of well-being, as well as taking into account the particular needs of the "Concrete Others". They also advocate a model in which the discursive power in the public sphere is not centralized, but allocated to multiple places.

If, at first, Habermas' discourse theory does not specifically address the gender issue in law, in his work Between Facts and Norms, the author specifically addresses the issue of gender and feminist movements. His analysis, however, is not sufficient to account for the whole transversal issue of gender and of perpetuated domination that permeates various fields. The author also does not reflect on the sexual division of labor and women's much larger load with reproductive work, encumbering their emancipation to participate in political decisions and resulting in a greater need on the part of women for social benefits provided by the State such as maternity leave, child care, aid and nursing homes, etc., since this universality is defined by the identification of experiences of a specific group of people as a paradigmatic argument of humans in general (white people, adult, male, Western, owners or liberal professionals).

With respect to reproduction, Habermas believes that it is a responsibility only of the mother and that, therefore, any social protection would generate a reflex discrimination, although he clarifies that he considers that this responsibility was attributed by means of a pragmatic-contextual interpretation, rather than a natural or biological matter. The author does not take into account that the State can also be responsible for children, and, moreover, he does not take into account that such protection should be seen not only from a maternity approach but also of paternity, generating duties and right for fathers. While salaried productive work constitutes the system, the reproductive, domestic and care work, performed in the private sphere of life, incorporates the concept of the life-world, legitimizing the sexual division of labor (FRASER, 1985, p. 102 and 115).

This article does not seek to defend the unilateral establishment of rights and policies. We ratify the opinion of Fraser and Benhabib, stating that Habermas' theory is a necessary starting point, since the communicative rationality, despite its demanding requirements, speaks the language of inclusion ${ }^{27}$. However, Habermas' discourse theory lacks the recognition of alternative publics and the existence of various public spheres, namely, the recognition of a pluralism that is not only social but also legal. Additionally, an emancipatory transformation of male-dominated capitalist societies requires a transformation of the roles and institutions that mediate them. While the roles of "worker" and "caregiver" continue to be fundamentally incompatible, it will not

\footnotetext{
${ }^{27}$ On this point, see Bittar (2011, p 672-673.): "The organization of the traces of repressed demands that have been communed by a set of social actors allow certain issues to appear and become visible in the political sphere, tending to point to a growing effervescence of demands for justice, which include the need to intensify communication, sharing and the universalization of inclusion".
} 
be possible to universalize either role for both genders, thus requiring some form of rapprochement between the two roles (FRASER, 1985, p. 118). Thus, in the words of Santos (2005, p 272.), "The politicization of domestic space - and therefore the feminist movement - is a key component of the new theory of democracy".

Society as a whole and women in particular should participate in the process of elaborating norms and policies in a democratic way, serving as a collective subject; however, we can not allow, as a result of power imbalances, for such participation to be merely formal, without taking into account the real needs and the realization of the principle of equality.

In this sense - and having such factual inequality, a fact recognized by the author - Habermas does not settle the issue of how to make the affected subjects - in this case, women - participants in the political process of delineating such rights. In other words, how these women will be part of the determination of the law and participate in the decision-making process, while being excluded a priori from the political process in a general way.

There is not, in Habermas' theory, a definition regarding who and how women's empowerment will be realized, as Habermas's public sphere is exclusive in practice, making access difficult for certain groups of race, class and gender. To the extent that such women should be part of the delineation of such rights, they should have the ability (training), independence and strength in so-called decision-making. However, the author himself points out the alarming feminization of poverty and the fact that this problem creates a vicious circle in decision-making, since the higher female poverty is, the less women are able to speak out about their rights, and the less that they have a chance to outline their needs and rights, the poorer they will be.

Brazil is currently in $80^{\text {th }}$ place in the UNDP's gender inequality index (GII), in which the first place is Sweden, as the country with the least gender inequality, ${ }^{28}$ and the last country $\left(146^{\text {th }}\right)$ is Yemen ${ }^{29}$.

The problem of gender equality is found today in the distribution of power expressed both in access to material resources and economic life, such as cultural issues as well as the decision-making bodies and leadership in society; that is, it concerns the issues of economic justice, as well as cultural and political justice, thus requiring a three-dimensional conception of justice, according to which the distribution demands correspond to the economic dimension of justice, the demands of recognition correspond to the cultural dimension of justice and the demands of representation correspond to the political dimension of justice.

Regarding the political participation of women, both in state policy and in other arenas of the public

\footnotetext{
${ }^{28}$ The first position in the world ranking does not guarantee absolute gender equality, and UNDP (2012) alerts that although some countries have managed to reduce many inequalities between men and women, they persist in all countries.

${ }^{29}$ UNDP (2012). This index takes into account data such as maternal mortality rates, fertility rates, seats in the national parliament, the number of people with at least secondary education completed disaggregated by sex, participation rate in the labor force disaggregated by sex, contraceptive prevalence rate and prenatal care. Note that Brazil fell from $70^{\text {th }}$ place to the $80^{\text {th }}$ position from 2008 to 201 , although the absolute values of this index have improved with regard to Brazil.
} 
space such as labor unions, the issues related to election and their gender-insensitive rules, together with maldistribution and false recognition based on gender, deny parity of political participation to women, and such problems belong to the sphere of the demands of representation and problems of injustice of political-common misrepresentation $^{30}$. Thus, the claims for gender quotas, as well as other forms of positive discrimination that promote the participation of women in public spaces and decision-making processes, seek to remove the political obstacles that block the equal participation of those who, in principle or at least formally, are already included in the political community (FRASER, 2010, p. 20-22).

One of the ways to empower women and enable their participation in decision-making processes and in the control of their own lives can occur with the participation of social groups. The actions of women in unions and in their leadership positions is one way of enabling women's empowerment, as well as to provide greater legitimacy of legal norms regarding gender equality, through an amalgamation process between union organizations, with the private sphere and non-state movement and the instances of decision-making.

Women's participation in unions provides a greater possibility for women to exercise power and citizenship in the public space in which democracy is built, enabling women to participate more in decisionmaking processes, while enhancing their political capital, since the participation of women in such sorts of social movements, besides serving as a regrouping space, also serves as a base and training for those women to participate in larger public spaces.

The workers' organizations can act in deliberative spheres in various ways: in addition to their specific role as a form of pressure against employers for better working conditions and through the establishment of collective norms, they participate in society, including the establishment of various public policies. In this vein, trade unions have a seat and a voice, for example, in the process of establishing public policies for women nationwide. As an example of participation in gender policy, the following workers' organizations can be mentioned, which had representatives when drafting the Second National Policy Plan for Women, as representatives of civil society organizations: Articulação Nacional de Mulheres Trabalhadoras Rurais - ANMTR, Central Única dos Trabalhadores - CUT, Confederação Geral dos Trabalhadores - CGT, Confederação Nacional dos Trabalhadores em Educação - CNTE, Confederação Nacional dos Trabalhadores na Agricultura CONTAG, Federação Nacional das Trabalhadoras Domésticas - FENATRAD and Força Sindical.

Freedom of association is a right that is linked to the construction of workers' citizenship as well as the construction and maintenance of democracy, and emerges as a basic premise for the organization of union bodies, in the Democratic State based on the Rule of Law, and the right to freedom of association must be designed as a

\footnotetext{
${ }^{30}$ At least within the Brazilian legal system, these are issues of injustice of ordinary-political misrepresentation, since women are not excluded, a priori, from the decision-making processes of such organizations.
} 
fundamental human right, as it enables the balance of forces necessary to guarantee working conditions and to build an efficient production system (SILVA, 2008, p. 66-67). Thus, the freedom of association, the right to information and the right to be heard by the government allow the holders of such rights to make themselves visible and audible in the very process of constructing rights, and constitute themselves as social guarantees of rights (SCHWARZ 2011, p.162).

One of the consequences of freedom of association is the guarantee to unions of their negotiating function, enshrined in Convention no. 98 of the ILO, highlighting the need to adopt appropriate measures to encourage workers and employers to develop negotiation procedures (SILVA, 2008, p. 70).

Although there is no express agreement in this regard, ILO has various documents declaring the importance of increasing women's participation in decision-making bodies of unions. Among these documents is the Resolution on gender equality at the heart of decent work, in 2009, product of the $98^{\text {th }}$ International Labour Conference that deals specifically with the centrality of gender equality in the search for decent work and stresses the need for measures that increase the number of women in social dialogue, in unions, in collective bargaining and in all decision-making processes.

Despite the acknowledged importance of women's participation in the activities of unions and in their deliberative and decision-making bodies, this participation has always been small.

The discussion of gender issues among the working class in Brazil emerged in the seventies, primarily in some unions of the state of São Paulo. During that period, the number of women strikers was significant and in some factories, where the percentage of women was high, the strike movement was in fact triggered by them. Despite the significant participation of women in strikes that emerged in that period, their participation in union assemblies and meetings was insignificant ${ }^{31}$.

In the eighties, unions began to be more concerned about the issue of working class women and the participation of women in trade union structures, causing the first women's commissions or secretariats of the union federations to be created with the purpose of both discussing discrimination in the labor market within the union movement, as well expanding the role of women in union organizations. Nevertheless, the number of women in union leadership positions remained small and the conditions of their participation were disadvantaged compared to men's ${ }^{32}$.

In the nineties, gender issues continued to be discussed in the union space, although in a period that was not very conducive to union demands in general. Some issues were incorporated into union policies, but several others experienced difficulty in their implementation ${ }^{33}$.

\footnotetext{
${ }^{31}$ In this sense, see Souza-Lobo (2011).

${ }^{32}$ In this sense, see Souza-Lobo (2011)

${ }^{33}$ In this sense, see Leone and Teixeira (2010).
} 
Despite the undeniable advances in women's participation in trade unions, in general, the participation of female workers in decision-making bodies remains low. In 1992, the percentage of unions chaired by women in all of Brazil was 6\%. By 2001, that number had increased to only $10 \%{ }^{34}$. Regarding the participation of women on the boards of trade unions, in 2001, out of a total of 15,961 trade unions, 5,667 had no women on their boards, 5,579 had up to $25 \%$ women on their boards, 3,280 had $26 \%$ to $50 \%$ women on their boards, 912 had $51-75 \%$ women on their boards, 499 had 76-100\% women on their boards and 24 unions did not disclose ${ }^{35}$. Out of those 15,961 unions, in 2001, only 1,618 had women in a position of presidency, 3,907 had women in a position of $1^{\text {st }}$ secretary, and 2,558 had women in a position of $1^{\text {st }}$ treasurer ${ }^{36}$.

The difference between the sexes is not just regarding the number of management positions in unions, but also the type of positions that men and women occupy in union bodies, with positions related to care, which is considered typically female work, leaving men with positions with more valued tasks that require and generate higher levels of political capital.

As for the union federations, some of these organizations stipulated affirmative action measures to combat the lack of women in their decision-making bodies in the nineties: CUT, CTB, UGT and Força Sindical. Although there are minimum quotas set aside in most union federations, currently only two of the unions have the minimum percentage of $30 \%$ of women in leadership positions. Moreover, in none of the unions analyzed above do women occupy positions in presidency, treasury or general secretary. They generally occupy positions in women's secretariats, labor relations, communication, race and environment, citizenship and human rights, employment and professional training, training and culture, racial equality, environment, welfare and retirement, and public services.

Actions in favor of gender equality within unions have been historically hampered by various barriers. Some of these barriers occur due to reasons of gender biases outside the unions which have repercussions on trade union actions, such as the concentration of women in low-skilled functions with high turnover, the inclusion of women in the labor market, mainly, in unipersonal production units, including those who work on their own behalf and in domestic employment, besides other precarious forms. This precariousness of labor relations influences the union movement and contributes to the lack of new forms and strategies to attract affiliated women workers and encourage women's participation in union life.

Other difficulties, however, are born within the unions themselves, as a result of the sexual division of labor in society which defines the roles of men and women in a stereotypical manner. The union movement, in

\footnotetext{
${ }^{34}$ Brazil (2010). IBGE data. Latest available data, noting that such data are from 2001, therefore there is a large gap in statistical studies on the subject of women's presence in decision-making bodies of trade unions.

${ }^{35}$ Brazil (2010). IBGE data. Latest available data.

${ }^{36}$ Brazil (2010). IBGE data. Latest available data.
} 
general, continues to maintain the concept that identifies workers as a homogeneous group with identical interests and claims, with the argument that the gender issue atomizes the class struggle.

Furthermore, the very organization of the union, based on the daily life of males, excludes women, as it does not take into account the overburden with household chores and unfavorable conditions for most women workers to participate in union life, such as the lack of nurseries in union events and the times of union activities, which are incompatible with the double shift on which women work.

Finally, the union space is essentially masculine, also, in terms of dynamics of participation, speech, language and interests, as they have leadership styles, participation dynamics, speech, language and uses of time that are opposed to the behaviors that the women have been taught and to which they are accustomed, requiring them, therefore, to adapt to these contexts.

Women's participation in union negotiations and in their boards is important not only with regard to the direct results of their participation in the norms agreed to by the unions, but it also has an impact on women's accumulation of political capital, since the union arena plays an important role in shaping the personalities that occupy the political spaces of decision-making.

It is therefore necessary to increase women's participation in the existing dialogue structures that are still dominated by men, such as unions and other worker organizations, in order to achieve economic, cultural, and political equality. Thus, to ensure that women workers can effectively exercise decision-making positions in unions, affirmative action measures must be taken in order to combat existing difficulties in the possession and exercise of these positions, both within and outside of these unions.

ILO supports the need for the effective participation of all groups in society in decisions affecting their future, in order to reach an authentic and lasting development based on social justice ${ }^{37}$. In 1998, this organization pointed to the measures below as those which unions should take in order to encourage women's participation in union activities: adoption of policies that seek to improve working women's situation and incentivize women to seek leadership positions in unions, self-evaluation by the union to identify factors affecting women's participation in union activities at all levels, establishment of women's units and gender equality committees, reservation of positions for women in the executive body, inclusion of women in candidate lists for union elections, reservations of positions for women in union conferences, educational programs aimed at providing women development of their leadership skills, and information campaigns to raise the awareness of all employees with regard to gender issues $^{38}$.

Given the need to promote women's participation in unions and especially in their governing bodies, the

\footnotetext{
${ }^{37} \mathrm{ILO}(2005$, p. 45).

${ }^{38}$ ILO (1998, p. 5-6).
} 
main actions that these organizations take and can take to promote women's participation in leadership and deliberation bodies are: actions to increase the number of unionized women working in informal sectors; promotion of unionization of male/female workers without employment connection; greater openness on the part of unions for the creation of mechanisms aimed at expanding women's union association by organizing an appropriate structure for female union activists to participate in union activities; the creation of strategic alliances with other unions; formation of women's commissions, committees or departments, particularly in union federations and confederations; development of original or autonomous organizational initiatives; drawing up maps of the gender issue; establishing clauses on situations specific to the female workforce in conventions and/or collective agreements; instituting quota policies to integrate women into unions; formation of institutional spheres linked to the labor world, of bipartite or tripartite integration; the right to be heard and the right of expression in union assemblies and in collective bargaining; training offers to female union leaders; among others. Among such measures, some are more used by Brazilian trade union organizations, such as the establishment of quotas for women in the elections of these organizations; the organization of female workers in the informal economy through the creation of strategic alliances with other types of associations; the creation of specific instances of gender issues within the unions; instances of bipartite or tripartite integration; and the female workers' right to be heard and the right of expression in union assemblies and in collective bargaining.

The measure of establishing quotas or goals, adopted by the majority of Brazilian unions, along with the increase of women in the labor market, has enabled an increase of women as union directors, which raises the number of women leaders in unions.

The establishment of quotas signals the recognition of the existence of gender as a political principle, but it is not enough to end inequalities, since "this simple introduction can compromise the emptying of cultural content if it does not manage, in an organization composed of men and women, to produce multiple political renovations." In such case, unions, in addition to implementing quotas, must carry out innovations in the modalities of gender relations within their own organizations (CAPPELLIN, 1994, p. 287).

Although quotas have their effectiveness and importance, other instruments should be implemented for the participation of women in trade union organizations, such as women's training courses for exercising union leadership positions to provide knowledge and training regarding union matters, the framework of linguistic discourse and of other technologies of power necessary to achieve the satisfactory performance of the activities in leadership positions, in order to avoid or reduce the risk of female union leaders not acting effectively. Additionally, for effective results, the quotas established must be complied with by these organizations, which does not usually occur, for example, with all of the Brazilian unions that have stipulated quotas.

Another way of increasing women's participation in union life and in their decision-making bodies that 
has been implemented is the organization of female workers in the informal economy, through the creation of strategic alliances with other associations, such as cooperatives and non-governmental organizations, as well as the use of the union structure not only by members of the category.

Due to the limited participation of women in union activities, various organizations have created specific instances in order to strengthen their presence and to propose policies to deal with labor problems resulting from the gender issue. Although there is controversy regarding the potential of such instances to promote and insert gender issues into unions, these organizations generally end up being necessary spaces for the development of reflection and proposals regarding the demands of the workers. They create the risk, however, of isolating or segregating women's demands within the union structure, not transcending and not having an impact on the totality of workers and trade union culture.

A different, very useful way of promoting the participation of women workers is the development of original or autonomous organizational initiatives of women workers, parallel to the unions themselves, with the possibility of mutually benefitting from such parallel women's organizations and traditional trade unions by means of a coalition of these organizations.

The bipartite or tripartite integration instances are a space for the female worker union leaders to enter and activate women workers' issues within the framework of an equal opportunity policy, in dialogue with the state power, and a tripartite commission on gender and race has already been created in Brazil.

Unions can and must ensure the right to be heard and the right of expression in union assemblies and in collective bargaining, so that the group of women within that category can manifest themselves regarding their interests. For this, there must also be a guarantee of the right to information that unions have regarding labor relations in that category.

It should be noted that the role of the measures presented herein is merely exemplary, as affirmative action may take various forms, ranging from the more traditional - with more rigid mechanisms, with the establishment of quotas - to the wider and more promotional approach, such as offering women training courses for union leadership. There are, therefore, a number of measures that can be implemented by unions for the promotion of women's participation in their deliberation bodies, and several of these have already been implemented by some international union organizations, foreign and/or Brazilian.

\section{CONCLUSION}

Given this study, it can be concluded that although there is a significant amount of applicable legal norms providing for the right to gender equality in Brazil, these inequalities continue to persist, especially in the labor market. In order to bring effectiveness to the legal norms regarding women's human rights, it is therefore necessary 
to take affirmative action measures to enable women workers to effectively participate in political life and in processes of deliberation and decision-making.

One way to encourage this participation in political life is the participation of women workers in union organizations and in their deliberating bodies, as these unions are collective organizations that may increase the political capital of these women and improve their employment conditions through the effective participation of women in the preparation of conventions and collective bargaining agreements, which are legal norms applicable to these women workers by the unions, and set up, in turn, deliberative instances in systems of legal pluralism.

This female participation, however, is still scarce and fraught with many difficulties in its implementation. Thus, the various measures of affirmative action as ways to promote women's participation in union life and in their deliberating bodies should be taken into account in order to increase this participation.

\section{O PRINCÍPIO DA IGUALDADE DE GÊNERO E OS DIREITOS FUNDAMENTAIS E AS GARANTIAS DA PARTICIPAÇÃO DA MULHER NA ORGANIZAÇÃO DA UNIÃO NO BRASIL}

\section{Resumo}

O objetivo deste artigo é estudar a importância da participação das mulheres trabalhadoras nos órgãos dirigentes dos sindicatos como forma de combater a desigualdade de gênero no mercado de trabalho. Há um número significativo de normas legais aplicáveis no sistema jurídico brasileiro para combater a desigualdade de gênero, com uma abordagem repressiva. No entanto, as consequências negativas da divisão sexual do trabalho persistem, perpetuando papéis estereotipados de gênero. Por conseguinte, é imperativo não só garantir a igualdade de salários e condições de trabalho e a proteção contra a discriminação negativa, mas também garantir o acesso das mulheres ao mercado de trabalho através de ações afirmativas. Neste sentido, a participação das mulheres trabalhadoras nas atividades sindicais é um dos principais meios para garantir esse acesso, pois possibilita o empoderamento das mulheres, proporcionando maior possibilidade às mulheres de exercer poder e cidadania na esfera pública em que a democracia é construída maior legalidade e legitimidade das normas convencionais em matéria de igualdade de gênero, dado o papel normativo dos sindicatos. Para isso, a implementação de ações afirmativas é necessária para combater as dificuldades na participação das mulheres nesses órgãos de decisão.

Keywords: direitos fundamentais; gênero; Discriminação positiva; Sindicato; mulheres.

\section{REFERENCES}

ABRAMOVICH, Victor; COURTIS, Christian. Los derechos sociales en el debate democrático. Madrid: Bomarzo 2006.

BENHABIB, Seyla. Another universalism: on the unity and diversity of human rights. Proceedings and adresses of the American Philosophical Association. Newark: American Philosophical Association, v.81, n. 2, Nov. 2007, p. 7 32 . 

1992.

Situating the self: gender, community and postmodernism in contemporary ethics. New York, Routledge,

BERTOLIN, Patrícia Tuma Martins; CARVALHO, Suzete. A segregação ocupacional da mulher: será a igualdade jurídica suficiente para superá-la? In: ANDREUCCI, Ana Claudia Pompeu Torezan; BERTOLIN, Patrícia Tuma Martins (orgs.). Mulher, sociedade e direitos humanos. Homenagem à Professora Doutora Esther de Figueiredo Ferraz. Sao Paulo: Rideel, 2010, p. 179-210.

BITTAR, Eduardo Carlos Bianca. Justiça e emancipação: reflexões jusfilosóficas a partir do pensamento de Jürgen Habermas. São Paulo: Doctoral thesis submitted for Full Professorship at the Department of Philosophy and General Theory of Law, Faculty of Law, University of Sao Paulo, in 2011.

BJORNSDOTTIR, Kristin. The ethics and politics of home care. International Journal of Nursing. Studies n. 46, 2009, p. 732-739.

BRAZIL. Presidency of the Republic. Secretaria Especial de Política Para as Mulheres [Special Secretariat of Policies for Women]. Relatório anual do observatório Brasil da igualdade de gênero 2009/2010. Brasilia: Special Secretariat of Policies for Women, 2010.

IBGE - Brazilian Institute of Geography and Statistics. National Household Sample Survey. Available at: www.bge.gov.br. Accessed on 08/15/2008.

BRUSCHINI, Cristina; LOMBARDI, Maria Rosa. Work, education and income of women in Brazil in recent years. In: HIRATA, Helena, SEGNINI, Liliana (eds.). Organização, trabalho e gênero. Sao Paulo: SENAC, 2007, p. 43-88.

CANADAY, Margot. Promising alliances: the feminist critical theory of Nancy Fraser and Benhabib. Feminist Review. Palgrave Macmillan Journals, n. 64. Fiction and Theory: crossing boundaries, 2003, p. 50-69.

CAPPELLIN, Paola. Viver o sindicalismo no feminino. Revista Estudos Feministas. Special issue. Rio de Janeiro, CIEC/UFRJ, out.1994, p. 271-290.

CARVALHO, Osvaldo Ferreira de; COSTA, Eliane Romeiro. O princípio da proibição de retrocesso social no atual marco jurídico-constitucional brasileiro. Direito público. Sao Paulo: IDP- IOB, ano 7, n. 34, jul-ago 2010, p.7-40.

CELIBERTI, Lilian; MESA, Serrana. La equidad de Género en los países del MERCOSUR Montevideo: CEFIR - Centro de Formación para la Integración Regional [Training Center for Regional Integration], 2010.

COMPARATO, Fábio Konder. A afirmação histórica dos direitos humanos. 3rd ed. Sao Paulo: Saraiva, 2003.

CRENSHAW, Kimberlé. Documento para o encontro de especialistas em aspectos da discriminação racial relativos ao gênero. Revista estudos feministas. Florianópolis: Instituto de Filosofia e Ciências Sociais, ano 10, n.1, 2002, p. 171-188.

FRASER, Nancy. Scales of justice: reimagining political space in a globalizing world. New York: Columbia University, 2010.

Justice interruptus: critical reflections on the 'Postsocialist' condition. New York: Routledge, 1997.

Pragmatism, feminism, and the linguistic turn. In: BENHABIB, Seyla; BUTLER, Judith; CORNELL, 
Drucilla; FRASER, Nancy (orgs.). Feminist contentions. New York: Routledge, 1995, p. 157-172.

What's Critical about Critical Theory? The Case of Habermas and Gender. New German Critique, n. 35, Special Issue on Jurgen Habermas, 1985, p. 97-131.

PERSEU ABRAMO FOUNDATION/SESC. Mulheres brasileiras e gênero nos espaços público e privado. 2010. Available in: http://www.fpabramo.org.br/sites/default/files/pesquisaintegra.pdf. Accessed on: $12 / 11 / 2011$.

HABERMAS, Jürgen. The Inclusion of the Other: Studies in Political Theory 2nd Ed. Sao Paulo: Loyola, 2004. Between Facts and Norms. Vol. II. Rio de Janeiro: Tempo Brasileiro, 1997.

HEINEN, Jacqueline. Politiques sociales et familiares. In: HIRATA, Helena et al. (Coord.). Dictionnaire critique du feminisme. Paris: Presses Universitaires de France, 2000, p. 147-151.

HIRATA, Helena. Teorias e práticas do care: estado sucinto da arte, dados de pesquisa e pontos em debate. In: FARIA, Nalu; MORENO, Renata (eds.) Cuidado, trabalho e autonomia das mulheres. Sao Paulo: SOF, 2010, p. $42-56$.

Mundialização, divisão sexual do trabalho e movimentos feministas transnacionais. Cadernos de crítica feminista. SOS CORPO- Instituto feminista para a democracia: Recife, Ano III, n. 2, dez. 2009, p. 80-107.

HITA, Maria Gabriela. Gênero, ação e sistema: a reinvenção dos sujeitos. Lua nova. Revista de cultura e política. Sao Paulo: CEDEC, n. 43, 1998, p.109-130.

KERGOAT, Danielle. Division sexuelle du travail et rapports sociaux de sexe. In: HIRATA, Helena et al. (Coord.). Dictionnaire critique du feminisme. Paris: Presses Universitaires de France, 2000, p. 35-44.

LEONE, Eugenia Troncoso; TEIXEIRA, Marilane Oliveira. As mulheres no mercado de trabalho e na organização sindical. Paper presented at the XVII National Population Studies Meeting held in Caxambu- MGBrazil, 20 to 24 September, 2010. Available at: $<$ http://www.abep.nepo.unicamp.br/encontro2010/docs_pdf/tema_8/abep2010_2200.pdf>. Accessed on $12 / 24 / 2010$.

LIMA, Firmino Alves. Teoria da discriminação nas relações de trabalho. Rio de Janeiro: Elsevier, 2011.

INTERNATIONAL LABOR ORGANIZATION. Equality at work: tackling the challenges. Global report under the follow-up to the ILO Declaration on fundamental principles and rights at work. Report of the DirectorGeneral. Geneva: ILO, 2007. Available at: http://www.ilo.org/wcmsp5/groups/public/---dgreports/--dcomm/---publ/documents/publication/wcms_publ_9221128717_en.pdf. Accessed on 07/12/2011.

Manual de capacitação e informação sobre gênero, raça, pobreza e emprego: capacidade de organização e negociação: poder para realizar mudanças. Brasilia: ILO, 2005.

Giving women a choice. Gender equality: a guide to collective barganining. Geneva: ILO, 1998.

Available at: http://actravitcilo.org/english/library/socdiag/v07601.htm. Accessed on: 11/18/2011.

PIOVESAN, Flávia. Direitos humanos e o direito constitucional internacional. 8th ed. São Paulo: Saraiva, 2007.

PISARELLO, Gerardo. Los derechos sociales y sus garantías. Madrid: Trotta, 2007.

SANTOS, Boaventura de Sousa. Pela mão de Alice. O social e o político na pós-modernidade. 10th ed. São Paulo: 
Cortez, 2005.

SARLET, Ingo Wolfgang. Dignidade da pessoa humana e direitos fundamentais na Constituição federal de 1988. 5. ed. Porto Alegre: Livraria do Advogado, 2007.

SCHWARZ, Rodrigo Garcia. Los derechos sociales como derechos humanos fundamentales. Su imprescindibilidad y sus garantias. Mexico City: Miguel Angel Porrúa, 2011.

SILVA, Otavio Pinto e. A questão da liberdade sindical. In: Marcus Orione Gonçalves Correia; Jorge Luiz Souto Maior. (Eds.). Curso de Direito do Trabalho. São Paulo: Editora LTr, 2008, v. III, p. 66-85.

SOUZA-LOBO, Elisabeth. A classe operária tem dois sexos. Trabalho, dominação e resistência. 2nd Ed. São Paulo: Brasiliense/Secretaria Municipal de Cultura, 2011.

UNITED NATIONS DEVELOPMENT PROGRAMME. World Development Report 2012: Gender Equality and Development. Available in: Outline http: //www.generoracaetnia.org.br/publicacoes/Banco\%20Mundial\%2057627.pdf. Accessed on: 10/5/2011

Trabalho enviado em 27 de julho de 2016.

Aceito em 06 de outubro de 2016. 